\title{
SUMBER DANA DAN PRINSIP OPERASIONAL BMT
}

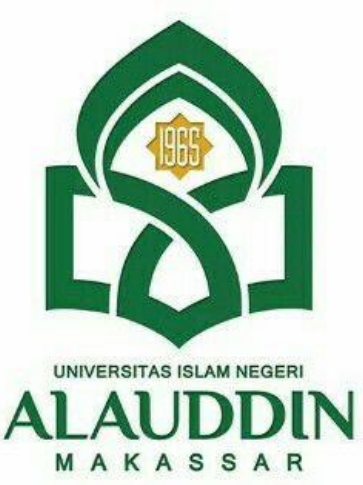

MAKALAH

Diseminarkan Pada Mata Kuliah Pengantar Ekonomi Program Studi Ekonomi Islam Semester V Tahun 2021

Oleh :

Ummu Khaerunnisa

NIM. 90100119072

Dosen Pengajar:

Sirajuddin, ME

PROGRAM STUDI EKONOMI ISLAM FAKULTAS EKONOMI DAN BISNIS ISLAM UIN ALAUDDIN MAKASSAR 


\section{KATA PENGANTAR}

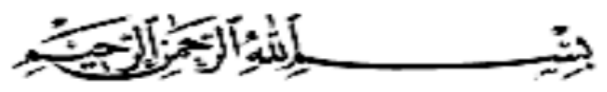

Puji syukur penulis panjatkan ke hadirat Allah swt. Atas rahmat dan hidayahNya sehingga penyusunan makalah ini dapat diselesaikan. Shalawat dan salam semoga tercurahkan kepada Nabi Mauhammad saw, keluarga dan para sahabatnya. tesis dengan judul: "Sumber Dana dan Prinsip Operasional BMT" ini dimaksudkan untuk memenuhi salah satu syarat lulus pada mata kuliah Manajemen BMT. Penulis menyadari bahwa penyelesaian makalah ini tidak akan terwujud tanpa bantuan, bimbingan dan dukungan dari berbagai pihak.

Maros, 15 November 2021

Penyusun 


\section{DAFTAR ISI}

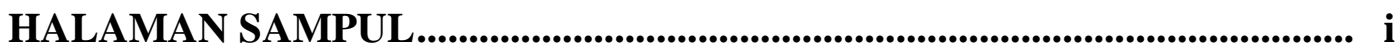

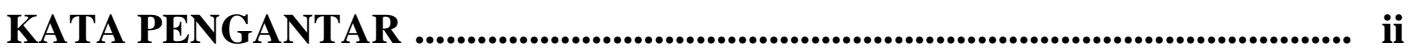

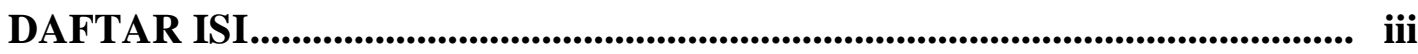

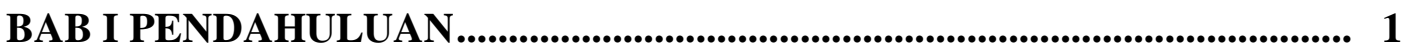

A. Latar Belakang ..................................................................... 1

B. Rumusan Masalah ....................................................................... 1

C. Tujuan dan Manfaat Penelitian .................................................... 2

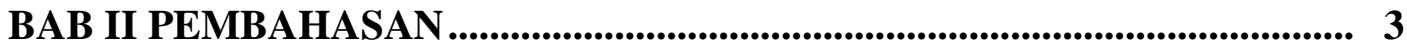

A. Pengertian Baitul Maal Waa Tamwil .......................................... 3

B. Sumber Dana Baitul Maal Waa Tamwil ....................................... 4

C. Prinsip Operasional Baitul Maal Waa Tamwil.............................. 5

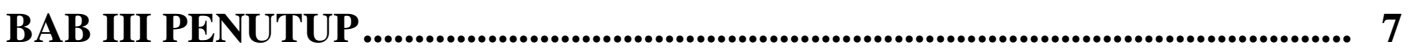

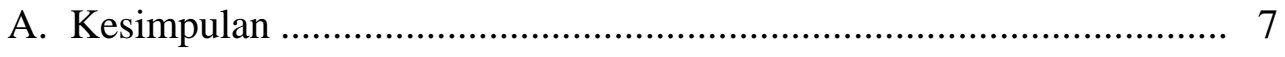

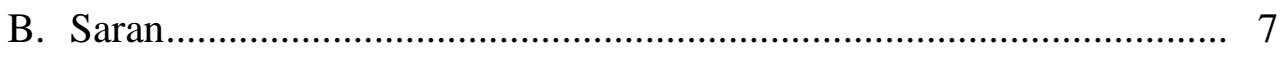

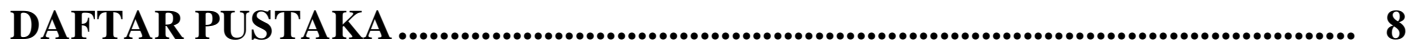




\section{BAB I}

\section{PENDAHULUAN}

\section{A. Latar Belakang}

Baitul Maal Waa Tamwil merupakan sebuah wadah untuk menghimpun dana dari masyarakat atau nasabah dalam bentuk simpanan yang nantinya dana tersebut diolah dan dialokasikan ke berbagai pembiayaan seperti pembiaayaan mudharabah, musyarakah, murabahah, pinjaman, maupun pembiayaan kebajikan kepada masyarakat dan para pelaku usaha mikro (Solekha et al., 2021). Dikatakan juga BMT merupakan lembaga yang didirikan dan dikembangkan oleh masyarakat, yang memiliki penawaran produk dalam bentuk jasa dan keuangan dengan menggunakan berbagai akad syariah dalam segala aktivitasnya (Solekha et al., 2021).

Salah satu perangkat strategis dalam menopang kepercayaan adalah permodalan memadai, modal merupakan faktor yang amat penting bagi perkembangan dan kemajuan bank sekaligus menjaga kepercayaan masyarakat (Solihin, 2020)

\section{B. Rumusan Masalah}

Adapun sub masalah yang akan dibahas adalah:

1. Apa pengertian dari Baitul Maal Waa Tamwil (BMT)?

2. Apa saja yang termasuk sumber dana atau permodalan dari Baitul Maal Waa Tamwil? 
3. Apa saja prinsip operasional dari Baitul Maal Waa Tamwil ?

\section{Tujuan}

Sejalan dengan rumusan masalah yang telah dituangkan, maka tujuan makalah ini adalah sebagai berikut:

1. Untuk mengetahui pengertian Baitul Maal Waa Tamwil

2. Untuk mengetahui sumber dana atau permodalan dari Baitul Maal Waa Tamwil

3. Untuk mengetahui prinsip operasioanal dari Baitul Maal Waa Tamwil 


\section{BAB II}

\section{PEMBAHASAN}

\section{A. Pengertian Baitul Maal Waa Tamwil}

Lembaga keuangan syariah yaitu lembaga yang menyediakan jasa keuangan bagi masyarakat yang membutuhkan dana untuk mendirikan usaha baru dan juga sebagai jasa pinjaman atau tabungan agar masyarakat sekitar dapat mengembangkan usaha karena lembaga keuangan syariah sendiri tidak sematamata mencari keuntungan melainkan bertujuan unutk meningkatkan kesejahteraan masyarakat yang kurang mampuagar dapat mengentaskan kemiskinan di Indonesia (Solekha et al., 2021). Lembaga keuangan syariah yang ada di Indonesia terdiri dari 2 lembaga yaitu Bank dan non- bank. Salah satu lembaga keuangana non-bank yang ada di Indonesia yaitu Baitul Maal Waa Tamwil. Baitul Maal Waa Tamwil adalah balai usaha mandiri terpadu yang isinya berintikan bayt al-maal wa al tamwil dengan kegiatan mengembangkan usaha-usaha produktif dan investasi dalam meningkatkan kualitas kegiatan ekonomi pengusaha kecil untuk mendorong kegiatan menabung dan menunjang pembiayaan kegiatan ekonominya (Melina, 2020) 


\section{B. Sumber Dana Baitul Maal Waa Tamwil}

BMT dalam menjalankan pembiayaan kepada anggota, diperlukan permodalan yang memadai, adapun sumber permodalan dari BMT berasal dari lima sumber (Solihin, 2020):

a) Simpanan pokok. Simpanan pokok merupakan simpanan pokok yang harus dibayar saat menjadi anggita BMT. Besarnya dimpanan pokok harus sama. Pembayarannya dapat saja dicicil, supaya dapat menjaring jumlah anggota yang lebih banyak. Sebagai bukti keanggotaan, simpanan pokok tidak boleh ditarik selama menjadi anggota. Jika simpanan ini ditarik, maka dengan sendirinya keanggotaannya dinyatakan kembali.

b) Simpanan khusus. Simpanan khusus merupakan simpanan modal penyertaan, yang dapat dimiliki oleh individu maupun lembaga dengan jumlah setiap penyimpanan tidak harus sama, dan jumlah dana tidak mempengaruhi suara dalam rapat. Simpanan hanya dapat ditarik setelah jangka waktu satu tahun melalu musyawarah tahunan

c) Simpanan wajib, simpanan ini menjadi sumber modal yang mengalir terus setiap waktu. Besar kecilnya sangat tergantung pada kebutuhan permodalandan anggotanya. Besarnya simpanan wajib setiap anggota sama. Baik simpanan pokok maupun wajib akan turut diperthitungkan dalam pembagian Simpanan Hasil Usaha. 
d) Dana cadangan. Sejumlah dana yang diperoleh dari penyisihan sisa hasil usaha (SHU). Adapaun tujuan adanya dana cadangan adalah untuk memupuk modal sendiri dan untuk menutup kerugian BMT bila diperlukan

e) Modal penyertaan. Dana ini bersumber dari pinjaman pihak luar. Pihak luar yang dimaksud adalah mereka yang memiliki kesamaan sistem yakni bagi hasil, baik bank maupun non bank

\section{Prinsip Operasional Baitul Maal Waa Tamwil}

Menurut Pasal 1 butir (25) Undang-Undang No. 21 Tahun 2008 tentang Perbankan Syariah yang dimaksud pembiayaan adalah penyediaan dana atau tagihan yang dipersamakan dengan itu berupa transaksi bagi hasil dalam bentuk mudharabah dan musyarakah, sewa menyewa dalam bentuk ijarah atau sewa beli dalam bentuk ijarah muntahiya bittamlik, jual beli dalam bentuk piutang murabahah, salam dan istishna, pinjam meminjam dalam bentuk piutang qardh, dan sewa menyewa jasa dalam bentuk ijarah untuk transaksi multijasa (Rahmah, 2019).

Diantara pembiayaan BMT adalah Dalam mengelola dana yang ada BMT menggunakan prinsip operasioanl, Pembiayaan Murabahah adalah jual beli barang modal maupun konsumsi antara bank selaku penjual serta anggota selaku pembeli dengan nilai keuntungan dan jangka waktu pembayaran dimana harga perolehan diketahui oleh kedua belah pihak (Rahmah, 2019) . Pembiayaan $a l-B a$ 'i Bidhaman ajil,, Ba'i bidhaman ajil dikenal dengan jual beli tertanggung yaitu menjual sesuatu dengan disegerakan penyerahan barang-barang yang dijual 
kepada pembeli dan ditangguhkan pembayaran, dari segi bentuknya, jual beli ini berbeda dengan ba'i al-salam, yang mana pembayaran dilakukan secara tunai, sedangkan pengantaran barang ditangguhkan (Iswandi, 2017). Pembiayaan alMudharabah adalah prinsip bagi hasil setiap jenis usaha yang di dalamnya ada prinsip bagi hasil, maka akan ada pembagian hasil antara BMT dengan nasabahnya (Melina, 2020). Pembiayaan al-Musyarakah Syirkah secara etimologis mempunyai arti pencampuran, yakni percampuran salah satu dari dua harta dengan harta lainnya tanpa ada dibedakan antara keduanya (Iswandi, 2017). Rahn (Gadai) adalah suatu jenis perjanjian untuk menahan suatu barang sebagai tanggungan utang (Herviani, 2019). Prinsip non profit ini merupakan suatu prinsip yang sering disebut sebagai pembiayaan kebajikan atau pembiayaan yang bersifat sosial dan non komersial (Melina, 2020) 


\section{BAB III}

\section{PENUTUP}

\section{A. Kesimpulan}

Baitul Maal Waa Tamwil (BMT) adalah salah satu lembaga keuangan syariah non-bank untuk menghimpun dana dari masyarakat yang dimana prinsip operasionalnya sesuai dengan Islam, seperti mudharabah, murabahah, salam, istishna, musyarakah, Rahn dan Qardhul Hasan, dan lain sebagainya. BMT juga diharapkan dapat mengelola dananya dengan baik, karena permodalan poin penting untuk kelancaran suatu usaha.

\section{B. Saran}

Demikianlah tugas penyusunan makalah ini. Harapan kami dengan adanya makalah ini bisa menjadikan kita untuk lebih memahami tentang Sumber Dana dan Prinsip Operasional BMT, Serta dengan harapan semoga dapat di pahami dan bermanfaat bagi para pembaca. Kritik dan saran sangat kami harapkan, mengingat makalah masih jauh dari kesempurnaan. 


\section{DAFTAR PUSTAKA}

Herviani, S. (2019). Fikih Transaksi Pembiayaan Logam Mulia Pada Pegadaian Syariah CAB. Bone. Laa Maisyir : Jurnal Ekonomi Islam, 6 No. 1.

Iswandi, H. (2017). Pembiayaan BMT Al-Amin dalam Meningkatkan Usaha Mikro di Kota Makassar. Laa Maisyir : Jurna; Ekonomi Islam, 4 No. 2.

Melina, F. (2020). Pembiayaan Murabahah Di Baitul Maal Wat Tamwil (Bmt). Jurnal Tabarru': Islamic Banking and Finance, 3(2), 269-280. https://doi.org/10.25299/jtb.2020.vol3(2).5878

Rahmah, S. (2019). Kualitas Sumber Daya Manusia Terhadap Pembiayaan Murabahah Pengembangan Umkm. Laa Maisyir: Jurnal Ekonomi Islam, 6(259), 90-111.

Solekha, Y. A., Syariah, J. A., Ekonomi, F., Pekalongan, I., Syariah, J. A., \& Ekonomi, F. (2021). Baitul Maal Wa Tamwil Sebagai Lembaga Keuangan Mikro Syariah Pemberdaya Ekonomi Umat (Konsep Dan Teori). Journal of Sharia Finance and Banking, 1(1), 44-58.

Solihin. (2020). Manajemen Permodalan BMT (Baitul Maalwat Tamwil) Di Masa Pandemi COVID-19. Lentera, 19 No. 1, 131-142. 